\title{
LATE PLEISTOCENE POLLEN FLORA WITH LARIX FROM TILL-COVERED ESKER AT HIETAMÄKI, OSTROBOTHNIA, WESTERN FINLAND
}

\author{
BRITA ERIKSSON and RAIMO KUJANSUU
}

\begin{abstract}
ERIKSSON, BRITA and KUJANSUU, RAIMO, 1994: Late Pleistocene pollen flora with Larix from till-covered esker at Hietamäki, Ostrobothnia, western Finland. Bull. Geol. Soc. Finland 66, Part 2, 53-66.

A till-covered layer of clay, fine sand and organic-bearing silt was found at Hietamäki near Haapajärvi, Ostrobothnia (Pohjanmaa), western Finland. The organic-bearing silt layer is an infill sediment in a dead ice hollow within a glaciofluvial formation interpreted as an esker. The esker is covered by till, at the base of which is a layer or lense of clay $1.5 \mathrm{~m}$ thick. On the basis of pollen content, the layers of clay and organic-bearing silt were deposited during the Eemian interglacial stage. Pinus-Picea-Larix forests mixed with Betula and Alnus possibly represent a regressive phase of the late Eemian vegetational development, when thermophile trees had already withdrawn from the area.
\end{abstract}

Key words: stratigraphy, till-covered esker, organic-bearing silt, pollen analysis, correlations, interglacial environment, Eemian, Weichselian, Haapavesi, Ostrobothnia, western Finland.

Brita Eriksson and Raimo Kujansuu: Geological Survey of Finland, FIN-02150 Espoo, Finland.

\section{INTRODUCTION}

Numerous interglacial and interstadial organic sediments/sediments with organic matter have been described from Ostrobothnia in western Finland (cf. Niemelä \& Tynni 1979, Grönlund 1991a, Eriksson 1993). Deposits interpreted as Eemian interglacial in age have been found at several sites, e.g. Norinkylä (Niemelä \& Tynni 1979, Donner 1988, Grönlund 1991b, Eriksson 1993), Evijärvi (Eriksson et al. 1980), Ollala (Forsström et al. 1987, 1988), Vimpeli II (Aalto et al. 1989), and Vesiperä and Viitala (Nenonen et al. 1991). None of the deposits covers the entire interglacial cycle; their palynostratigraphy usually reflects the climatic conditions of an early and/or temperate Eemian 
substage. The deposits at Oulainen (Forsström 1982, Donner 1988, Forsström et al. 1987) and Marjamurto (Peltoniemi et al. 1989) have been correlated with the Early Weichselian Brørup interstadial. The place names of all the interstadial and interglacial finds referred to in the text are marked on the map in Fig. 1.

In 1988, Hannu Peltoniemi of the Finnish National Road Administration, found a till-covered clay deposit in a gravel pit at Hietamäki, in the village of Vattukylä, Haapajärvi, in central Ostrobothnia. In the same year, M. Saarnisto and R. Kujansuu investigated the site and collected samples from the clay sequence (Hietamäki A). They found a silt deposit containing organic matter overlain by till and sand from which M. Saarnisto took two sets of samples (Hietamäki B and C) in 1989. All the samples were taken with a spade from an exposed cutting. The sand pit has since been landscaped.

\section{SITE DESCRIPTION}

The Hietamäki site is located at $64^{\circ} 6^{\prime} \mathrm{N}, 25^{\circ} 25^{\prime} \mathrm{E}$ (map sheet $243308, \mathrm{x}=7111.90, \mathrm{y}=2569.85, \mathrm{z}=$ 115) $5 \mathrm{~km}$ southeast of the urban centre of Haapavesi municipality (Fig. 2).

The Haapavesi area is characterized by till-covered glaciofluvial formations which deposited during the Saalian deglaciation (Peltoniemi et al. 1989). The almost total lack of subglacial glaciofluvial formations of the last melting stage of the continental ice sheet reflects the exceptional glaciodynamic and subglacial palaeohydrological conditions that prevailed in the area.

Hietamäki hill is the southeastern end of a three-part esker-like formation, about $2 \mathrm{~km}$ long and $150-400 \mathrm{~m}$ wide, which rises $20-25 \mathrm{~m}$ above the floor of the Pyhäjoki river valley at about $90 \mathrm{~m}$ a.s.l. The rocky area in the east is mainly at $110-130$ $\mathrm{m}$ a.s.l, or at about the same elevation as the highest summits of the esker. The southeastern end of the esker skirts the rocky area.

North of Pyhäjoki, east and north of the urban centre of Haapavesi, there is another chain of till-covered glaciofluvial formations that geomorphologically can also be interpreted as an esker (Ollala esker, cf. Forsström et al. 1987, 1988). It is possible that both this esker and the Hietamäki formation belong to the same chain as the Marjamurto till-covered formation (cf. Peltoniemi et al. 1989).

At present the major part of Ostrobothnia belongs to the middle boreal vegetation zone; the forests in the area are thus mainly coniferous with birch.

\section{LITHOSTRATIGRAPHY}

The generalized lithostratigraphy of Hietamäki is shown in Fig. 3. Lowermost there are glaciofluvial gravel and sand, which form a depression filled with up to $4 \mathrm{~m}$ of bluish grey or almost black, gyttja-bearing coarse silt and fine sand. The content of organics is $2-3 \%$ as measured with loss-on-ignition. The gyttja-bearing silt is covered with a layer of stratified fine to medium sand, 1-3 m thick. Approximately in the middle of the layer there is an intensely deformed, 0.5 -m-thick stratum with silty bands. The sand layer is covered with till resting unconformably on the underlying sands such that parts of the deformed stratum are directly under the till. The till unit is composed from bottom to top of 1) a fairly large clay plate, about $1.5 \mathrm{~m}$ thick, 2) a lodgement-type silty till with some clay clasts (Fig. 4) and 3) a waterlain, stratified till with thin silty bands. The formation is covered with a shallow $(<1 \mathrm{~m})$ Holocene gravelly shore deposit that grades into a sandy tombolo at the southeastern end of Hietamäki.

\section{POLLEN STRATIGRAPHY}

\section{Methods}

The samples were treated in the laboratory in cold HF (cold method; Måller 1953) for three days, after which the dissolved silica material was washed away with hot $10 \% \mathrm{HCl}$. The residue was then 


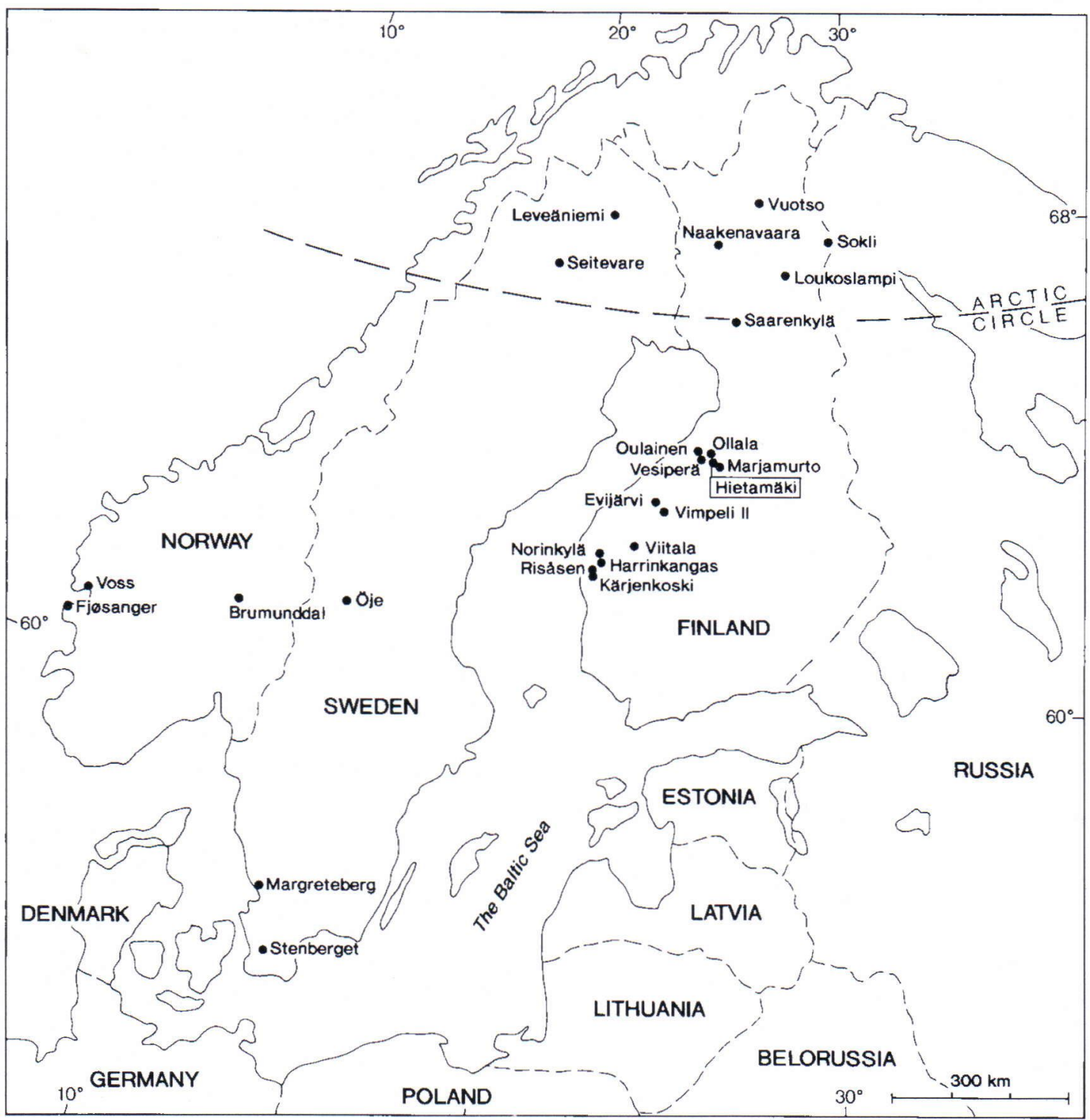

Fig. 1. Location map showing the Hietamäki site in Ostrobothnia, western Finland, and the interglaciall interstadial sites referred to in the text.

boiled in $10 \% \mathrm{KOH}$, and the coarse-grained fraction was removed by decanting. The material was mounted in glycerine, and whenever possible 300-500 arboreal pollen grains per sample were counted. One slide per sample was scanned for rare pollen taxa. The sums from which the percentages of the pollen and spore types were calculated are given in the diagrams.

\section{Hietamäki A}

Sixteen samples were taken from the clay deposit in 


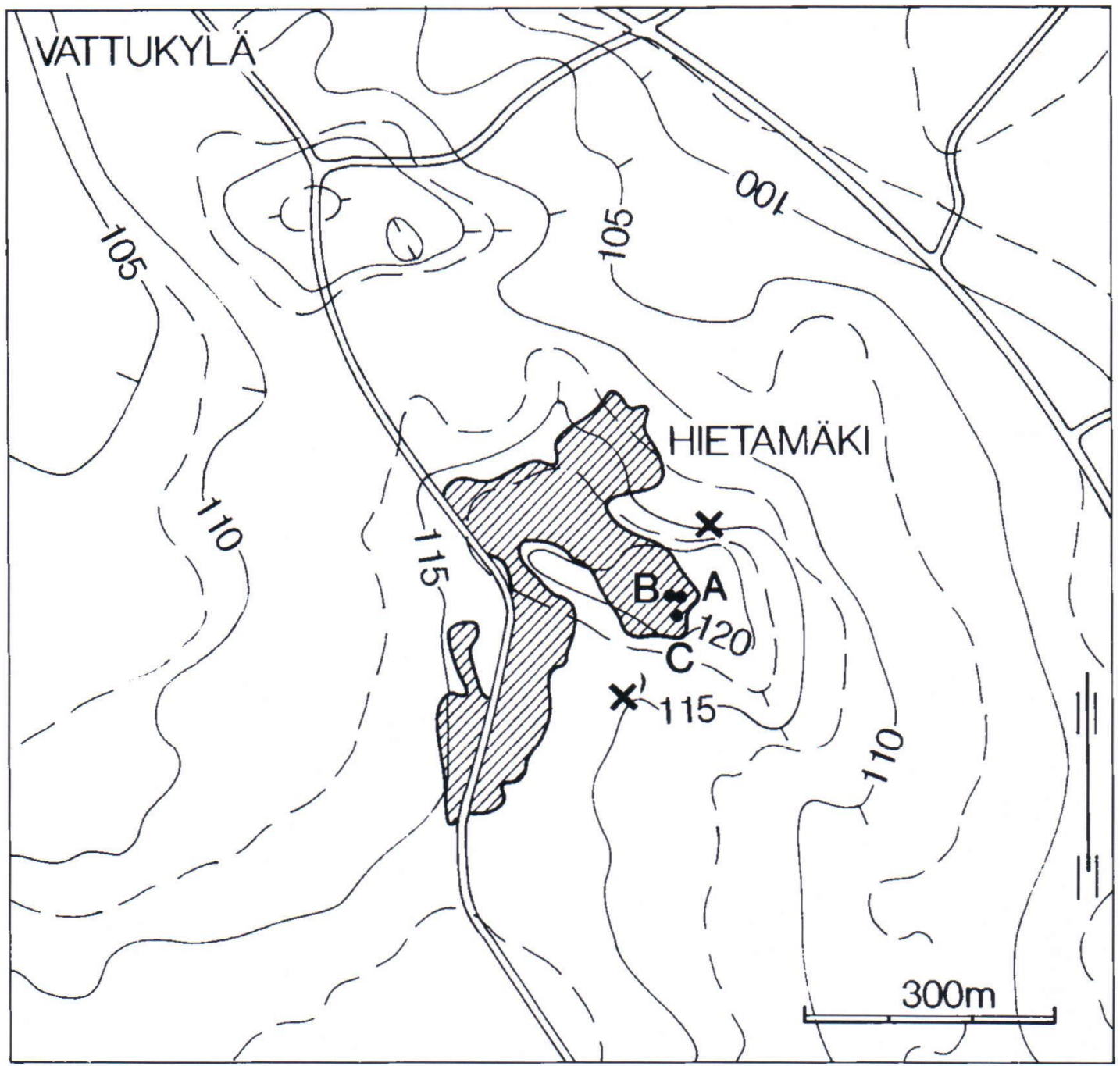

Fig. 2. Hietamäki, a till-covered glaciofluvial formation. Shown are Hietamäki sequences A-C and the profile (x$\left.x^{\prime}\right)$ of Fig. 3 in the gravel pit area (hatched). Contour lines at intervals of 2.5 and $5 \mathrm{~m}$.

the basal part of the till (2.0-3.5 m; cf. Fig. 3). Only four were analysed, as the relative pollen frequency of the samples was very low. The pollen flora of the samples was dominated by Pinus; scattered Picea, Betula and Alnus pollen grains occurred. One sample contained a Larix grain. In all samples, ericaceous pollen exceeded the sum of arboreal pollen. Sphagnum spores were also encountered. The clay deposit was investigated for diatoms, too, but they were not found.

\section{Hietamäki B}

The till and sand deposit was underlain by a deposit at least $4.0 \mathrm{~m}$ thick (the base was not seen) (5.0-9.0 $\mathrm{m}$, cf. Fig. 3) with alternating layers of gyttja-bearing 


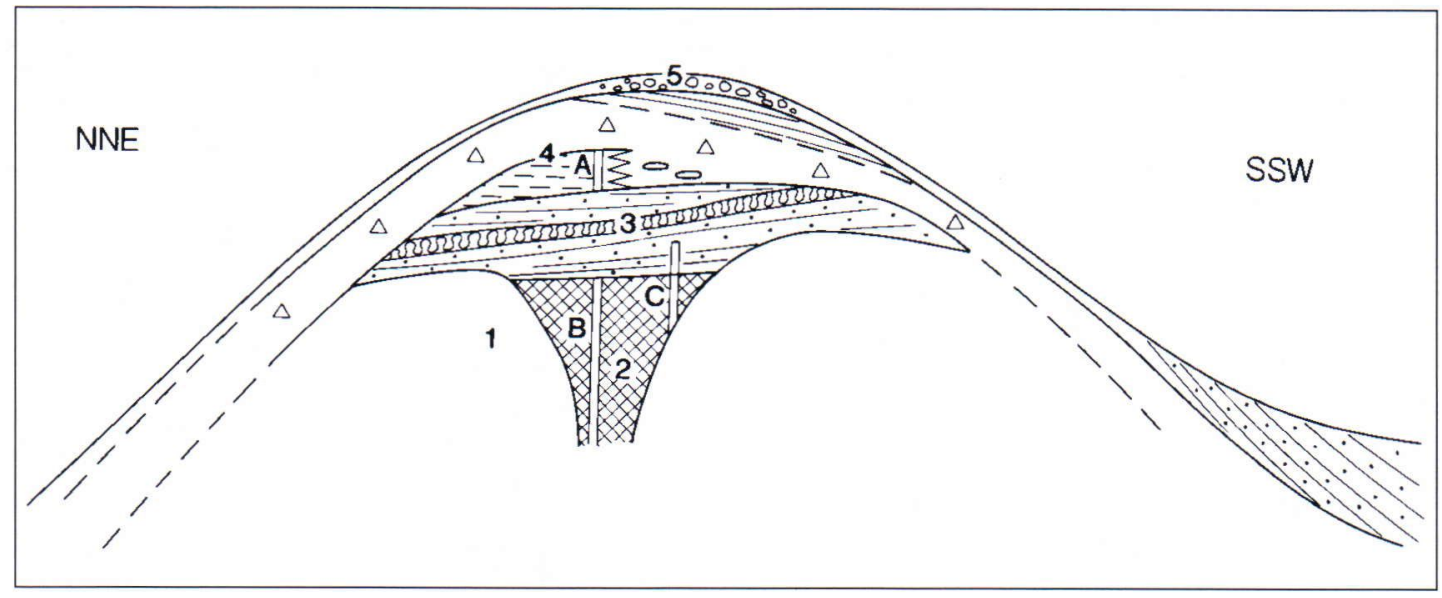

Fig. 3. Schematic cross-profile of the Hietamäki esker. 1. Glaciofluvial sand and gravel. 2. Silt and fine sand with organic material filling the kettle hole. 3. Medium and fine sand (with a deformed layer) resting on the glaciofluvial material and the kettle hole infill. 4. Till unit with a large clay float and smaller clay clasts (Fig. 4). 5. Holocene gravelly shore deposits grading into sandy (tompolo) deposits on the SSW flank of the esker.

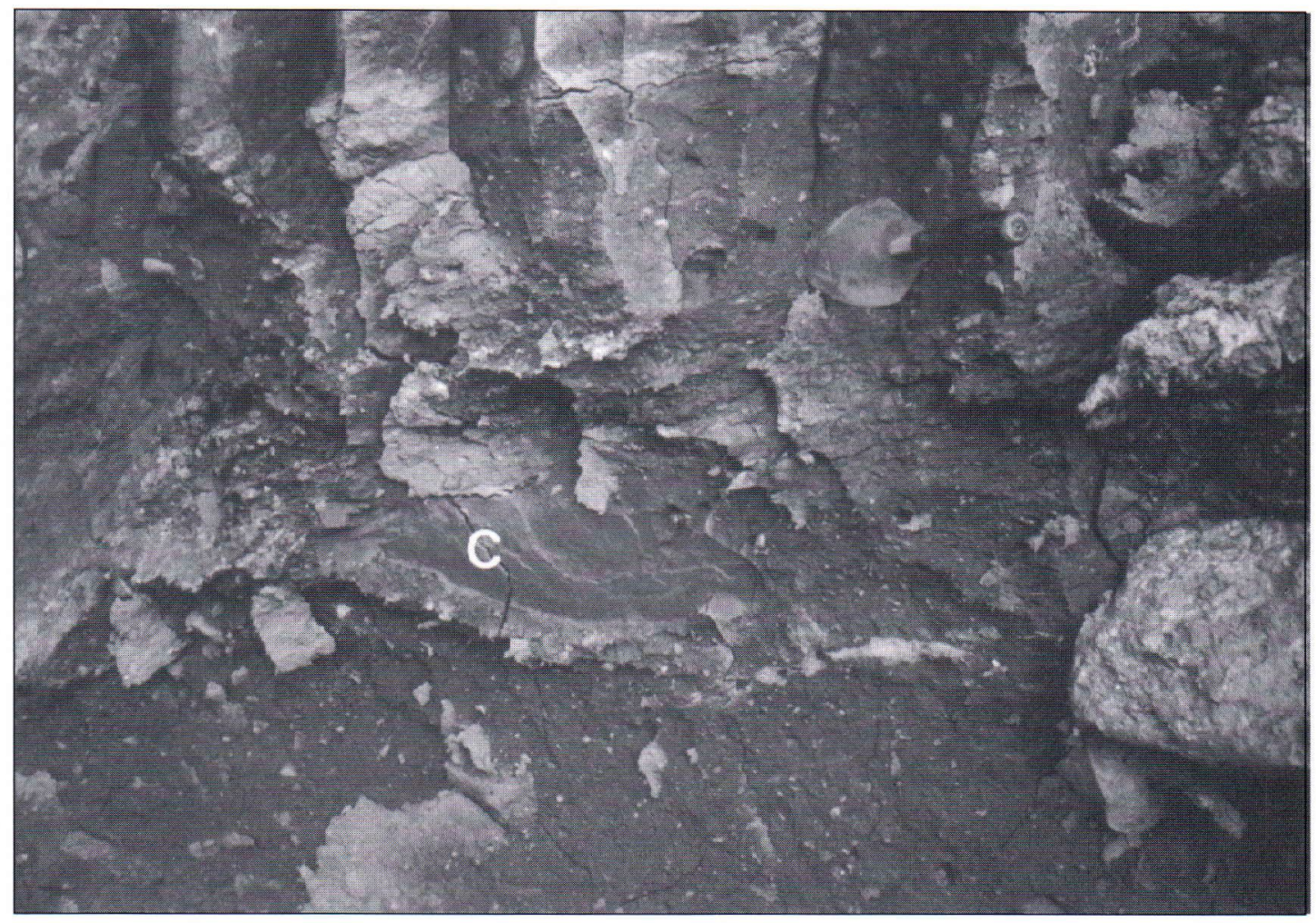

Fig. 4. Clay clast about $20 \mathrm{~cm}$ long in the lower part of the till sequence. 
silt and silt. Samples were taken from the deposit at intervals of $20 \mathrm{~cm}$. No diatoms were found. The pollen diagram (Fig. 5) shows one local pollen assemblage zone (p.a.z.).

Pinus-Picea-Larix-Ericaceae p.a.z.. In most of the spectra, arboreal pollen accounts for $60-70 \%$ of the total; in these spectra, Pinus dominates the arboreal pollen flora. The percentage of Pinus pollen in the whole pollen sequence varies in the range $12.8-42.1 \%$, the range for Betula is 5.7-57.3\%, for Picea 8.4-19.3\% and for Alnus 3.8-14.1\%. Larix exhibits a continuous pollen curve, in most samples its pollen values being within 1-3\% Scattered pollen grains of Quercus, Carpinus and Ulmus also occur in the arboreal pollen flora. Two cf. Abies pollen grains, one at a depth of $8.5 \mathrm{~m}$ and the other at $8.3 \mathrm{~m}$, may be redeposited.

The pollen of shrubs is either absent or accounts for less than $1 \%$ of the total pollen flora. The proportion of dwarf shrubs (Ericales) is high, being in the range $11.5-32.5 \%$. Most of the spectra contain about $10 \%$ herbaceous pollen, mainly that of grasses and sedges. The maximum for Sphagnum spores, $41.7 \%$, is at a depth of $6.3 \mathrm{~m}$.

At depth intervals of 8.1-7.9 $\mathrm{m}$ and 5.7-5.5 m, oxidized wood cell tissue was the only organic matter found. The absence of microfossils is probably due to an increased rate of either sedimentation or water flow. The dominance of Betula in the spectra from above the aforementioned depth intervals (that is, at depths of $7.7 \mathrm{~m}$ and $5.3 \mathrm{~m}$ ) is probably due to the fact that Pinus pollen grains remained afloat longer than the grains of other pollen. Some individual pollen grains of $B$. nana were identified but the proportion of $B$. nana in the pollen spectra could not be calculated because most of the Betula pollen grains were rather degraded. Coniferous pollen grains were broken.

\section{Hietamäki C}

At about $30 \mathrm{~m}$ from the Hietamäki B sequence there was a silt deposit also overlain by a deformed sand layer at a depth of $3.4-5.0 \mathrm{~m}$ (cf. Fig. 3), the middle part of which $(3.7-4.5 \mathrm{~m})$ contained organic matter. Samples were taken from the deposit at intervals of $10 \mathrm{~cm}$. The pollen spectra of sequence C (Fig. 6) are similar to those of sequence B and thus represent the same local pollen assemblage zone of Pinus-Picea-Larix-Ericaceae.

The Hietamäki silt deposit contains macroscopic oxidized wood remains. Microscopic investigations revealed abundant oxidized wood cell tissue and some charcoal particles in most of the samples. The samples from the lower part of sequence B, which is bluish black in colour, contained hard pieces of pollen-rich gyttja, about $0.5 \mathrm{~cm}$ in diameter. The pollen abundances were the same as in the silt. At a depth of $8.5 \mathrm{~m}$, there was a piece of gyttja-coated deciduous wood about $3 \mathrm{~cm}$ long and $0.5 \mathrm{~cm}$ wide.

The relative frequency of arboreal pollen in the gyttja layers of sequences B and C was fairly high. Many samples had a few pollen grains of Picea, probably of $P$. omorika, and less than $0.5 \%$ well-preserved Pre-Quaternary coniferous pollen. All samples had a pollen flora with Helianthemum and Epilobium grains, and most of them contained Valeriana pollen, too, at least outside the counted slide traverses.

\section{Vegetational interpretation}

The pollen flora in the silt deposit at Hietamäki reveals that the area belonged to the coniferous vegetation zone at the time the organic material deposited. The forests supported Pinus, Picea, Larix and Betula. The proportion of ericaceous plants (Ericaceae and Empetraceae) in the field layer was high; the ericaceous pollen grains are mainly of the Vaccinium type. Alnus stands grew in damp places. Helianthemum probably thrived on the warm southern slopes of the esker, and the local vegetation included Epilobium, Thalictrum and Valeriana. The soil was acidic and paludified.

\section{CORRELATIONS AND DISCUSSION}

The Hietamäki organics-bearing silt deposit is the 


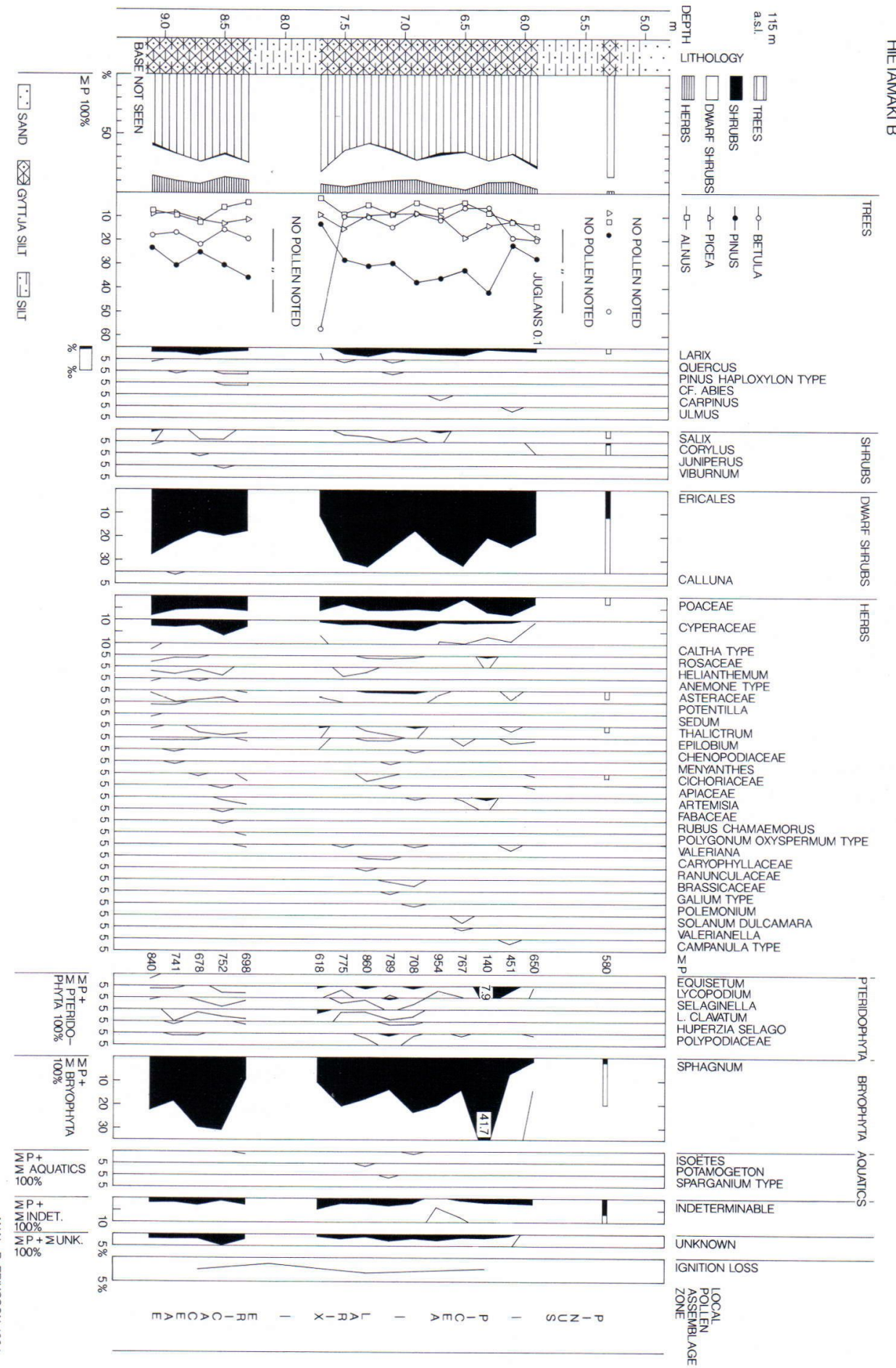




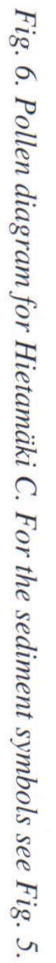

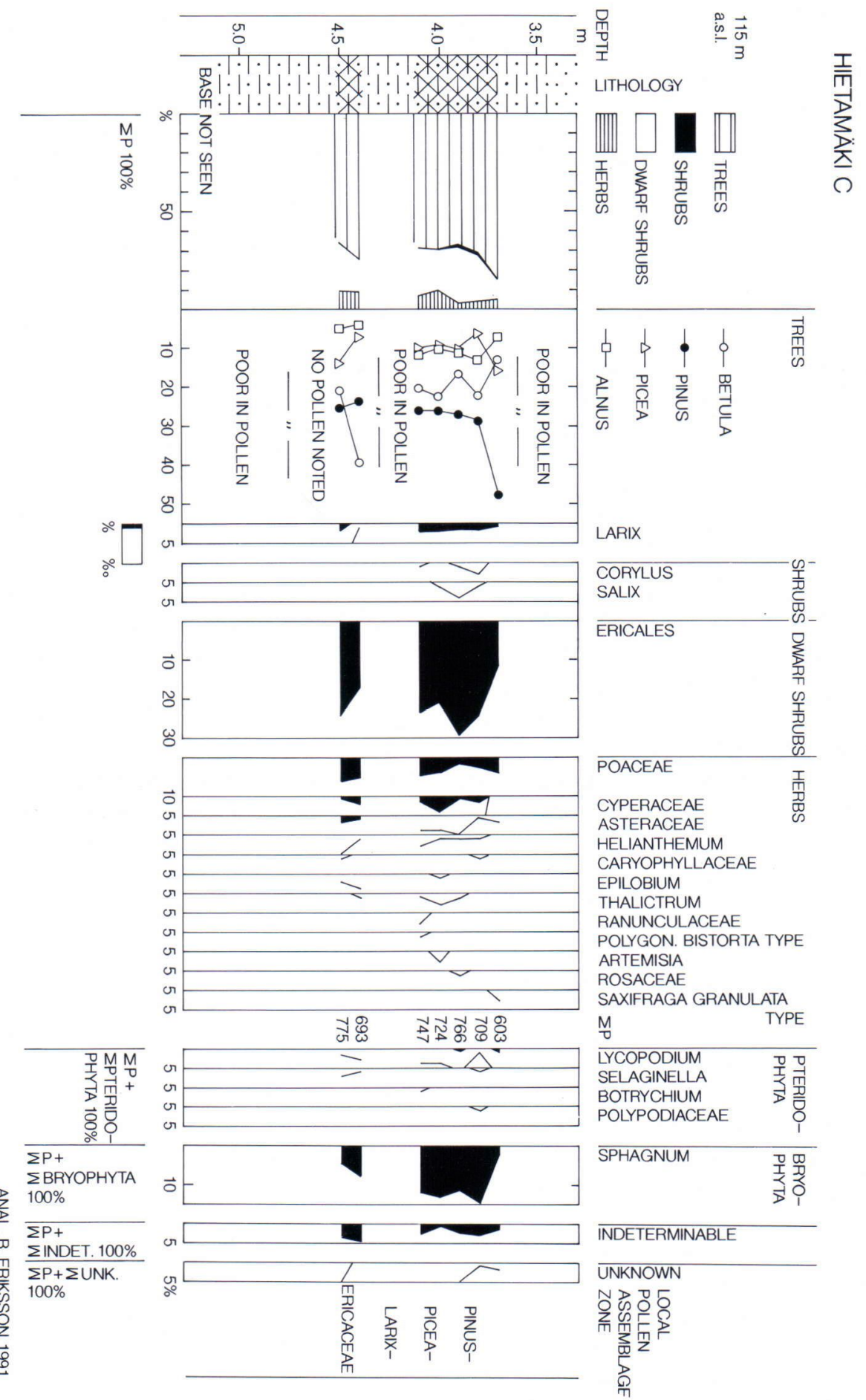


only interglacial/interstadial deposit yet found in Ostrobothnia to have a pollen assemblage showing that Larix was part of the permanent tree population. The pollen diagram of the Evijärvi interglacial deposit (Eriksson et al. 1980) has one Larix pollen grain in the upper part of the Betula-Alnus-PiceaCorylus zone; the Oulainen deposit, which was first interpreted as Eemian interglacial (Forsström 1982) and later (cf. Forsström et al. 1987) as Early Weichselian interstadial in age, has a few individual pollen grains. Larix produces only very minor amounts of pollen, and the species has not grown in Finland during the Holocene epoch.

Two species of larch grow in Europe: Larix sibirica, whose range in the west extends to the White Sea and Lake Onega, and L. decidua, which grows in the mountain ranges of eastern Central Europe; both thrive on nutrient-rich soil. All larches are photobiotic species.

During the Holsteinian interglacial, coniferous forests covered large parts of northern Continental Europe, and Picea and Alnus already belonged to the Holsteinian flora at an early stage of the cycle. The forests were mainly composed of Pinus, Picea and Larix but included Alnus, too. Arboreal species now considered exotic, e.g. Picea omorika, grew in Poland and Estonia (Szafer 1954 and Liivrand 1984, 1991). Robertsson (1988) presented a Picea-Pinus-Larix pollen assemblage zone from the Öje deposit (Central Sweden) and correlated it with the late Eemian or possibly with the Holsteinian. García Ambrosiani (1990) identified Picea Sect. omorica, cf. Abies ssp., Pinus cf. cembra and remnants of Larix spp. in a macrofossil analysis, and correlated the Öje deposit with the Holsteinian mainly on the basis of these coniferous components.

In Finland, the Naakenavaara peat deposit (Finnish Lapland), which has the extinct herb species Aracites interglacialis as the main peat-forming plant, is the only deposit interpreted as Holsteinian interglacial in age (Aalto et al. 1992). In the upper part of the pollen diagram, Larix has a continuous curve of a few per cent; a cone and several fragments of needles of Larix were also found in the peat.

The history of vegetation in Europe during the
Eemian interglacial is fairly well known, particularly for the North European Plain (cf. Watts 1988), where it was very uniform. At the end of the interglacial vegetation cycle, Pinus became more common while Picea was still a forest-forming species (regional pollen assemblage zone 6). Towards the end of the interglacial, Picea declined and paludification was intensified (regional zone 7). The incipient Weichselian glaciation is indicated by the increasing abundance of herbs and ericaceous plants in the vegetation cover. A few pollen grains of Larix have been found in a late Eemian (E VII) deposit in northwestern Germany (Menke \& Tynni 1984). In the final stage of the Eemian, Larix was part of the vegetation in Poland (cf. Mamakova 1989).

Larix pollen does not exist in the pollen sequences of Leveäniemi in Swedish Lapland (Robertsson 1971) or of Fjøsanger in southern Norway (Mangerud et al. 1981), both of which cover the Eemian vegetation cycle almost completely. Larix is also absent from the Seitevare deposits in Swedish Lapland, which are attributed to the latter part of the last interglacial (Robertsson \& Rohde 1988) and whose arboreal pollen spectra reflect open coniferous forests followed by birch forests; it is also absent from the pollen flora of Vinjedalen (Voss), a peat deposit in southern Norway (Eide \& Sindre 1987) fully dominated by Picea. Larix pollen does occur, however, in the deposits of Stenberget (Berglund \& Lagerlund 1981) and Margreteberg (Påsse et al. 1988) in southern Sweden. In the Stenberget sequence, there are intermittent occurrences of Larix in local pollen assemblage zone Sb-5, in which the Betula-dominant pollen flora contains about $10 \%$ Picea and Alnus in most of the samples. Berglund, who correlates the zone with the very end of the Eemian interglacial and possibly also with the incipient Weichselian glaciation (regional zones E7 and W1?), considers that Larix grew in the area at that time. A few Larix pollen grains have also been found in the Eemian Early Weichselian transition zone of the Margreteberg sequence.

All the interglacial sites in Ostrobothnia have 
been interpreted as Eemian (cf. Eriksson 1993), and their pollen stratigraphy as reflecting the pre-, early- and late-temperate substages of the interglacial vegetation cycle. The pollen assemblage of the latter is dominated by Betula and Alnus, and the proportion of Pinus is low. Picea forms a continuous curve, rising in the Evijärvi sequence (Eriksson et al. 1980) to a dominant position. The Corylus curve is continuous, and pollen grains of Carpinus occur at least sporadically. The Vimpeli II sequence probably deposited after the Eemian climatic optimum and before the withdrawal of conifers (Aalto et al. 1989). Pinus pollen dominates the total pollen flora; the abundance of Picea is up to about $10 \%$ and the Alnus curve remains under $5 \%$. The absence of deposits of the preceding temperate substage hampers the correlation of Vimpeli II with other pollen sequences in Ostrobothnia.

The Saarenkylä Eemian interglacial deposit in Peräpohjola (north of Ostrobothnia) (Sutinen 1992) contains up to $5 \%$ Larix pollen (unpublished data). Pollen grains of Larix have also been found in several Eemian interglacial deposits in Finnish Lapland (cf. Hirvas 1991). However, Loukoslampi (Hirvas 1991) and Sokli (Forsström 1990) are the only two deposits with Larix pollen where the pollen sequences exhibit more than one pollen assemblage zone. A well-preserved unbroken trunk of Larix was found in the Vuotso deposit (Mäkinen 1982).

Larix grains are found among the pollen flora of Early Weichselian interstadial deposits at several sites in northwestern Europe. Andersen (1961) showed that Larix pollen occurs in Brørup interstadial deposits in Denmark. In Germany (Behre \& Lade 1986) and Poland (Mamakova 1989), Larix grew during the Brørup and Odderade stages; the pollen values are highest for the late Brørup stage, when the arboreal species included Pice $a$ and Alnus, too. The Brumunddal peat deposit in Norway (Helle et al. 1981) has also been correlated with the Brørup stage; there the arboreal pollen flora of the Larix-Juniperus-Cyperaceae pollen assemblage zone is characterized by the persistent presence of Pinus, Larix and Picea pollen.

In Ostrobothnia, near Hietamäki, there are two sites with deposits interpreted as belonging to the Early Weichselian Brørup interstadial: Oulainen (Forsström 1982, Forsström et al. 1987) and Marjamurto (Peltoniemi et al. 1989) (Fig. 1). After a brief Betula stage, their pollen stratigraphy shows a long Pinus stage in which Picea pollen grains occur only intermittently, and the discontinuous Alnus curve does not rise above $3 \%$.

At the time that the interstadial deposits correlated with the Early Weichselian in Finnish Lapland (cf. Hirvas 1991) and northern Peräpohjola (Korpela 1969) were forming, subarctic Betula forests grew throughout the region. According to Forsström (1988), the northern limit of Pinus forest was in the Peräpohjola area during the Brørup interstadial, that is, about $300 \mathrm{~km}$ south of its present limit.

The forest types represented by dominant tree species and their pollen values in the Hietamäki silt deposit are fairly similar to those of the Naakenavaara (Aalto et al. 1992), Öje (Robertsson 1988, García Ambrosiani 1990) and Estonian (Liivrand 1984, 1991) Holsteinian deposits, except that the latter contain more pollen of temperate deciduous trees and Corylus, and also spores of thermophile Osmunda. Should the organic matter in the Hietamäki silt deposit be of the Holsteinian interglacial in origin, the pollen assemblage of the deposit reflects the vegetation that prevailed at the end of a warm substage.

The pollen values for Picea and Alnus in Hietamäki sequences $\mathrm{B}$ and $\mathrm{C}$ clearly reflect warmer climatic conditions than does the pollen stratigraphy of the deposits in Ostrobothnia interpreted as Early Weichselian. Thus, the Hietamäki deposit is unlikely to have originated during the Early Weichselian interstadial.

The pollen flora of Hietamäki clearly indicates a cooler climate than do the pollen sequences of the other interglacial deposits in Ostrobothnia, with the exception of Vimpeli II. The pollen assemblage of the Hietamäki sequence is best correlated with the local assemblage zone Sb-5 of Stenberget (Berglund \& Lagerlund 1981) and the zones of Margrete- 
berg (Påsse et al. 1988) indicating the end of the Eemian. In the regional pollen stratigraphy of northwestern Europe, the pollen flora of Hietamäki could probably be correlated with zones E 6-7 (cf. Andersen 1966) and E VI-VII (Menke \& Tynni 1984, Behre \& Lade 1986).

Conditions favourable for the formation of a depositional basin for gyttja-bearing silt arose when a block of ice buried in an esker during the pre-Late Weichselian deglaciation melted, and a kettle hole formed. This was subsequently filled by geological processes. However, as our excavations did not reach the bottom of the depression, only the final stages of the kettle hole filling could be established.

The filling of pre-Late Weichselian kettle holes has been described from southern Ostrobothnia in both fluvial (Gibbard et al. 1989) and aeolian milieus (Kujansuu 1992, Hütt et al. 1993).

According to Gibbard et al. (1989), the fossiliferous sediments at Harrinkangas, Kauhajoki, are basin infill formed as the Eemian Sea withdrew as a result of uplift, and the basin came under the influence of flowing water. 'Overall the sequence seems to record the advance of a delta-like sediment wedge from the south, probably marking the iliflow of a stream' (op. cit.). This model calls for intense glacial erosion in the surroundings of Harrinkangas. The present topography of the area is not consistent with the view that the basin had once come under the influence of a stream.

The fill in a depression or kettle hole in glaciofluvial sediments at Kärjenkoski, Isojoki; Risåsen, Kristiinankaupunki; and Norinkylä, Teuva, is of a different type (Kujansuu 1992, Hütt et al. 1993). After the Saalian deglaciation, a thin $(<0.5$ $\mathrm{m}$ ) layer of clay or silt deposited on the bottom of the depressions, followed by about $1 \mathrm{~m}$ of sand during a shallow water stage. This is what happened at Harrinkangas, too, before the deposition of the fossiliferous sediment. During the Eemian interglacial, a podzol layer evidently developed in the sand (Hütt et al. 1993), which, under altered climatic conditions, that is, the periglacial conditions of the Early Weichselian, was covered with aeolian and pluvial sand containing dust and pieces of charcoal. Cryoturbation deformed the sand under the prevailing periglacial conditions, and when the continental ice sheet advanced to southern Ostrobothnia the depressions were filled with proglacial (glaciolacustrine?) sands and eventually with till (Kujansuu 1992, Hütt et al. 1993).

The gyttja-bearing silt at Hietamäki could be a deltaic sediment deposited in a kettle hole in much the same way as the Harrinkangas deposit (cf. Gibbard et al. 1989). However, the Hietamäki deposit lies in a place where the existence of a stream or brook would have implied really substantial glacial erosion within a large area. As the existence of numbers of till-covered old formations in the area suggests weak regional glacial erosion (cf. Peltoniemi et al. 1989), it is highly unlikely that glacial erosion substantially altered the topography in the surroundings of Hietamäki.

Nor is it likely that the silt deposited in shallow water, e.g. in a lagoon of the Eemian Sea, because, at the time referred to by the pollen flora, the Eemian Sea had already withdrawn from the adjacent Ollala area, which is located at approximately the same elevation (Forsström et al. 1988). The sedimentation basin had obviously been isolated from the other waterways, being a depression resembling a modern kettle hole pond and hydraulically connected only with groundwater. Consequently, the water level in the basin was bound to variations in the groundwater table. In addition to rainfall, the groundwater table in the basin was controlled by hydraulic connections and impermeable deposits on the lower slopes of the esker. Obviously the groundwater table was high enough for the Hietamäki kettle hole to contain water.

To start with, the sedimentation rate in the kettle hole was evidently low but then it gained momentum, permitting the gyttja-bearing silt layer to deposit in a rather short time. The increase in wind velocity and/or the increase in precipitation eroded the ground around the kettle hole and transported material into it. The stratified fine sand that covers the organics-bearing silt is probably glaciolacustrine, mainly deltaic bottom set beds that deposited at an 
early glacial stage before the advancing continental ice sheet covered the area and deposited till on the formation. The clay plate on the bottom of the till bed was clearly transported to the site by the continental ice sheet.

\section{CONCLUSIONS}

The pollen in the gyttja-bearing silt/silt at Hietamäki was most probably originally deposited during the Eemian interglacial. The Pinus-Picea-Larix forests mixed with Betula and Alnus reflected by the pollen spectra may represent a stage of Late Eemian regressive vegetation development when thermophile trees had already withdrawn from Ostrobothnia.

According to Forsström (1990; Fig. 3), Larix spread to Finnish Lapland from the east during the temperate substage of the Eemian. During the Eemian interglacial, Larix grew in Peräpohjola and Finnish Lapland at the same time as Picea. At the end of the interglacial when the climate cooled, Larix probably spread southwards to Ostrobothnia.

The pollen flora might also reflect the conditions of the Holsteinian interglacial, but the preservation of deposits of that age on a glaciofluvial formation still revealing esker-like features does not seem plausible.

The mode of formation of the Hietamäki organics-bearing silt deposit is not easy to explain, because there are some details in the lithostratigraphy and biostratigraphy that are poorly compatible. The simplest explanation is that the sediment really did deposit at the end of the Eemian interglacial. A pond developed in an esker kettle hole that rapidly filled with aeolian and pluvial mineral matter. The grain size distribution and the presence of oxidized and charred wood material are suggestive of this type of sedimentation. The topography of the area does not support the concept that the deposit is an in-situ deltaic sediment.

Another possibility is that the kettle hole did not fill until the altered, periglacial conditions of the Early Weichselian prevailed, when the surroundings of the kettle hole were submitted to aeolian erosion. Under Eemian climatic conditions, the vegetation fixed the mineral matter both in and around the kettle hole. When the Late Eemian interglacial passed into the Early Weichselian stadial, which was characterized by periglacial conditions, the vegetation cover protecting the soil deteriorated rapidly. Aeolian and pluvial forces attacked the surficial soil layer and rapidly eroded the podzol $\mathrm{A}_{0}$ horizon and the underlying mineral soil, a sandy glaciofluvial deposit. Material transported by wind and rainwater deposited in depressions, such as the kettle hole at Hietamäki, where, owing to the altered hydrogeological conditions of the stadial (elevated groundwater table), there was a small kettle hole pond. This type of redeposition is, however, not suggested by either the pollen grains, which are mainly well preserved with the exception of the Betula-dominant spectra, or the high relative frequency of pollen.

With the filling of the kettle hole, the gyttja-bearing deposit was eventually covered with a few metres of sand. The continental ice sheet remodelled the Hietamäki formation and deposited a till cover on it. The load and shearing of the ice then deformed the Hietamäki sand deposit.

The clay layer in the basal part of the till bed obviously derives from ancient clayey interglacial deposits in the Pyhäjoki river valley that were eroded and mixed with the depositing till by the ice sheet. In places, as at Hietamäki, a large clay plate retained its shape on the bottom of the till bed throughout the glacial period and was not intermixed with the till. This model may apply also to the formation of the gyttja-bearing silt; if it does, the entire sequence, its kettle hole infill included, that now covers the glaciofluvial deposit was transported to the present site at the bottom of the ice sheet, and the gyttja-bearing silt deposit represents a deltaic sedimentation of the ancient River Pyhäjoki at the closing stage of the Eemian. In any case, the sediment deposited very rapidly because the pollen flora does not show any succession. The lack of diatoms can be attributed to the exceptional postdepositional conditions, which caused them to dissolve. 
ACKNOWLEDGMENTS: We are grateful to Professor Matti Saarnisto for sampling the site, critically reading the manuscript and making valuable comments.

Dr Tuulikki Grönlund is responsible for the diatom analyses. Satu Moberg drew the figures and Gillian Häkli translated the manuscript into English. To all of them we express our cordial thanks.

\section{REFERENCES}

Aalto, M., Donner, J., Hirvas, H. \& Niemelä, J., 1989. An interglacial beaver dam deposit at Vimpeli, Ostrobothnia, Finland. Geological Survey of Finland, Bulletin 348, 34 p.

Aalto, M., Eriksson, B. \& Hirvas, H., 1992. Naakenavaara Interglacial - A till-covered peat deposit in western Finnish Lapland. Bulletin of the Geological Society of Finland 64 (2), 169-181.

Andersen, S.Th., 1961. Vegetation and its environment in Denmark in the Early Weichselian Glacial (Last Glacial). Danmarks Geologiske Undersøgelse 2R, $75,175 \mathrm{p}$.

Andersen, S.Th., 1966. Interglacial vegetational succession and lake development in Denmark. Paleobotanist 15, 117-127.

Behre, K.-E. \& Lade, U., 1986. Eine folge von Eem und 4 Weichsel-Interstadialen in Oerel/Niedersachsen und ihr Vegetationsablauf. Eiszeitalter und Gegenwart 36, 11-36.

Berglund, B.E. \& Lagerlund, E., 1981. Eemian and Weichselian stratigraphy in South Sweden. Boreas $10,323-362$.

Donner, J., 1988. The Eemian site of Norinkylä compared with other interglacial and interstadial sites in Ostrobothnia, Western Finland. Annales Academiae Scientiarum Fennicae, A III, 149, 31 p.

Eide, F. \& Sindre, E., 1987. Late Eemian and early Weichselian sediments in the Vinjedalen valley, Vossestrand, West Norway. Norges geologiske undersökelse, Bulletin 409, 21-27.

Eriksson, B., 1993. The Eemian pollen stratigraphy and vegetational history of Ostrobothnia, Finland.
Geological Survey of Finland, Bulletin 372, 36 p.

Eriksson, B., Grönlund, T. \& Kujansuu, R., 1980. Interglasiaalikerrostuma Evijärvellä, Pohjanmaalla. Summary: An interglacial deposit at Evijärvi in the Pohjanmaa region, Finland. Geologi 32 (6), 65-71.

Forsström, L., 1982. The Oulainen Interglacial in Ostrobothnia, Western Finland. Acta Universitatis Ouluensis, Series A, 136, Geologica 4, 116 p.

Forsström, L., 1988. The northern limit of pine forest in Finland during the Weichselian interstadials. Annales Academiae Scientiarum Fennicae, A III, 147, 24 p.

Forsström, L., 1990. Occurence of larch (Larix) in Fennoscandia during the Eemian interglacial and the Brørup interstadial according to pollen analytical data. Boreas 19, 241-248.

Forsström, L., Eronen, M. \& Grönlund, T., 1987. On marine phases and shore levels of the Eemian Interglacial and Weichselian interstadials on the coast of Ostrobothnia, Finland. Geological Survey of Finland, Special Paper 2, 37-42.

Forsström, L., Aalto, M., Eronen, M. \& Grönlund, T., 1988. Stratigraphic evidence for Eemian crustal movements and relative sea-level changes in eastern Fennoscandia. Palaeogeography, Palaeoclimatology, Palaeoecology 68, 317-335.

García Ambrosiani, K., 1990. Macrofossils from the tillcovered sediments at Öje, Central Sweden. In: Pleistocene stratigraphy in Central and Northern Sweden - a reinvestigation of some classical sites. University of Stockholm, Department of Quaternary research, Report 16, Paper I, 10 p.

Gibbard, P., Forman, S., Salomaa, R., Alhonen, P., Jungner, H., Peglar, S., Suksi, J. \& Vuorinen, A., 1989. Pleistocene stratigraphy at Harrinkangas, Kau- 
hajoki, Western Finland. Annales Academiae Scientiarum Fennicae, A III, 150, 36 p.

Grönlund, T., 1991a. The diatom stratigraphy of the Eemian Baltic Sea on the basis of sediment discoveries in Ostrobothnia, Finland. Helsinki 1991.

Grönlund, T., 1991b. New cores from Eemian interglacial deposits in Ostrobothnia, Finland. Geological Survey of Finland, Bulletin 352, 23 p.

Helle, M., Sønstegaard, E., Coope, G.R. \& Rye, N., 1981. Early Weichselian peat at Brumunddal, southeastern Norway. Boreas 10, 369-379.

Hirvas, H., 1991. Pleistocene stratigraphy of Finnish Lapland. Geological Survey of Finland, Bulletin 354, $123 \mathrm{p}$.

Hütt, G., Jungner, H., Kujansuu, R. \& Saarnisto, M., 1993. OSL and TL dating of buried podsols and overlying sands in Ostrobothnia, western Finland. Journal of Quaternary Science 8 (2), 125-132.

Korpela, K., 1969. Die Weichsel-Eiszeit und ihr Interstadial in Peräpohjola (nördliches Nordfinnland) im Licht von submoränen Sedimenten. Annales Academiae Scientiarum Fennicae, A III, 99. 108 p.

Kujansuu, R., 1992. Palaeosols as Quaternary stratigraphical key horizons in Ostrobothnia, western Finland. Bulletin of the Geological Society of Finland 64 (2), 161-167.

Liivrand, E., 1984. The interglacials of Estonia. Annales Academiae Scientiarum Fennicae, A III, 138, 16 p.

Liivrand, E., 1991. Biostratigraphy of the Pleistocene deposits in Estonia and correlations in the Baltic region. University of Stockholm, Department of Quaternary Research, Report 19, 114 p.

Mamakowa, K., 1989. Late middle Polish glaciation, Eemian and early Vistulian vegetation at Imbramovice near Wroclaw and the stratigraphy of this part of the Pleistocene in Poland. Acta Palaeobotanica 29 (1), 11-176.

Mangerud, J., Sønstegaard, E., Sejrup, H.-P. \& Haldorsen, S., 1981. A continuous Eemian-Early Weichselian sequence containing pollen and marine fossils at Fjøsanger, western Norway. Boreas 10, 137-208.

Mäkinen, K., 1982. Tiedonanto Vuotson interglasiaalisesta lehtikuusen rungosta. Summary: Report on interglacial Larix trunk at Vuotso, Northern Finland. Geologi 34 (9-10), 183-185.

Menke, B. \& Tynni, R., 1984. Das Eeminterglazial und das Weichselfrühglazial von Rederstall/Dithmarschen und ihre Bedeutung für die mitteleuropäische Jungpleistozän-Gliederung. Geologisches Jahrbuch, A 76, 3-120.

Müller, H., 1953. Zur spät- und nacheiszeitlichen Vegetationsgeschichte des mittel-deutschen Trockengebiets. Nova Acta Leopoldina, Neue Folge 16:110, 67 p.

Nenonen, K., Eriksson, B.\& Grönlund, T., 1991. The till stratigraphy of Ostrobothnia, western Finland, with reference to new Eemian interglacial sites. Striae 34, 65-76.

Niemelä, J. \& Tynni, R., 1979. Interglacial and interstadial sediments in the Pohjanmaa region, Finland. Geological Survey of Finland, Bulletin 302, 48 p.

Peltoniemi, H., Eriksson, B., Grönlund, T. \& Saarnisto, M., 1989. Marjamurto, an interstadial site in a tillcovered esker area of central Ostrobothnia, western Finland. Bulletin of the Geological Society of Finland 43 (2), 209-237.

Påsse, T., Robertsson, A.-M., Miller, U.\& Klingberg, F., 1988. A Late Pleistocene sequence at Margreteberg, southwestern Sweden. Boreas 17, 141-163.

Robertsson, A.-M., 1971. Pollenanalytical investigation of the Leveäniemi sediments. In Lundqvist, J.: The interglacial deposit at the Leveäniemi mine, Svappavaara, Swedish Lapland. Sveriges Geologiska Undersökning, C 658, årsbok 65 (4), 82-103.

Robertsson, A.-M., 1988. A reinvestigation of the biostratigraphy of the till covered sediments at Pilgrimstad and Öje, central Sweden. In Robertsson, A.-M.: Biostratigraphical studies of interglacial and interstadial deposits in Sweden. University of Stockholm, Department of Quaternary Research, Report 10 (2), $53 \mathrm{p}$.

Robertsson, A.-M.\& Rodhe, L., 1988. A Late Pleistocene sequence at Seitevare, Swedish Lapland. Boreas 17, 501-509.

Sutinen, R., 1992. Glacial deposits, their electrical properties and surveying by image interpretation and ground penetrating radar. Geological Survey of Finland, Bulletin 359, 123 p.

Szafer, W., 1954. Pleistocene Stratigraphy of Poland from the Floristical Point of View (in Polish, with English summary). Annales de la Société Géologique de Pologne, Volume XXII, Annéé 1952, Fasc. 1, 99 p.

Watts, W.A., 1988. Late-Tertiary and Pleistocene vegetation history: Europe. In: Huntley, B. \& Webb, T. III (Eds.), Vegetation History. Kluwer, Dordrecht, 155-192. 